\title{
Adaptation of the Self-Compassion Scale for Use in Brazil: Evidences of Construct Validity
}

\author{
Luciana Karine de Souza ${ }^{1}$ \\ Programa de Pós-Graduação Interdisciplinar em Estudos do Lazer da Universidade Federal \\ de Minas Gerais, Belo Horizonte, MG, Brazil \\ Programa de Pós-Graduação em Psicologia da Universidade Federal do Rio Grande do Sul, \\ Porto Alegre, RS, Brazil \\ Claudio Simon Hutz \\ Departamento de Psicologia do Desenvolvimento e da Personalidade da Universidade \\ Federal do Rio Grande do Sul, Porto Alegre, RS, Brazil
}

\begin{abstract}
This study reports evidences of adaptation, construct validation, and reliability of the Self-Compassion Scale for use in Brazil. Self-compassion is a positive healthy attitude towards the self when facing suffering and difficulties. It encompasses self-kindness instead of self-judgment, mindfulness instead of over-identification, and common humanity instead of social isolation. A confirmatory factor analysis endorsed the six-factor structure (six subscales) of the original scale; adequate polychoric correlations were identified among subscales; a higher-order factor was confirmed via hierarchical model analysis; and internal consistency was .92. The scale is ready for application on Brazilian samples in continuing validation studies, for example, with available measures of social desirability, self-esteem, depression, and anxiety, as well as with similar constructs, such as self-acceptance, mindfulness, emotional selfregulation, and self-judgment.
\end{abstract}

Keywords: Self-compassion, adaptation, validity.

\section{Adaptação da Escala de Autocompaixão para Uso no Brasil: Evidências de Validade de Construto}

\section{Resumo}

O presente estudo relata evidências de adaptação, validação de construto e fidedignidade da Escala de Autocompaixão para uso no Brasil. A autocompaixão é uma atitude saudável e positiva direcionada ao self diante de situações de sofrimento e dificuldades. Abrange bondade consigo no lugar de autocrítica severa, mindfulness no lugar de sobreidentificação, e senso de humanidade em vez de isolamento social.

Mailing address: Universidade Federal do Rio Grande do Sul, Instituto de Psicologia, Programa de PósGraduação em Psicologia, Rua Ramiro Barcelos, 2600, térreo, Porto Alegre, RS, Brazil 90035-003. Phone: (51)3308-5261. E-mail: lukarides@gmail.com and claudio.hutz@gmail.com

Acknowledgments: K. Neff, L. Taborda, J. Natividade, J. Rique, A. Antoniazzi, J. Sarriera, and the 2012 research team of the Psychological Assessment Laboratory at Federal University of Rio Grande do Sul (UFRGS). Institutional support: Psychology Department of Federal University of Minas Gerais; Psychological Assessment Lab/UFRGS, and Centro de Análise de Dados em Psicologia (CAD-Psico) of the Graduate Program in Psychology at UFRGS.

Financial support: National Council for Scientific and Technological Development (CNPq-Brazil), post-doctoral scholarship, research project number 159687/2011-0. Ethical approval number 04345112.5.0000.5334. 
A análise fatorial confirmatória endossou a estrutura de seis fatores (seis subescalas) da escala original; correlações policóricas adequadas foram encontradas entre as subescalas; um fator de segunda ordem foi confirmado por modelagem hierárquica; e a consistência interna foi de 0,92 . A escala apresenta condições para uso com amostras brasileiras na continuidade de sua validação, por exemplo, com medidas disponíveis de desejabilidade social, autoestima, depressão e ansiedade, bem como constructos afins, como autoaceitação, mindfulness, autorregulação emocional e autocrítica.

Palavras-chave: Autocompaixão, adaptação, validade.

\section{Adaptación de la Escala de Autocompasión para Uso en el Brasil: Evidencias de Validez de Constructo}

\section{Resumen}

El estudio actual trata de evidencias de adaptación, validez de constructo y fidedignidad de Escala de Autocompasión para uso en el Brasil. La autocompasión es una actitud saludable y positiva dirigida al 'self' delante de situaciones de sufrimiento y dificultades. Abarca bondad consigo en lugar de autocrítica severa, mindfulness en el lugar de sobre identificación, y sentido de humanidad en vez de aislamiento social. El análisis factorial confirmatorio mostró una estructura de seis factores (seis subescalas) de la escala original; correlaciones policoricas adecuadas fueron encontradas entre las subescalas; un factor de segundo orden se confirmó por modelaje jerárquica y la consistencia interna fue de .92. La escala presenta condiciones para uso con muestras brasileñas en la continuidad de su validación, por ejemplo, con medidas disponibles de deseabilidad social, autoestima, depresión y ansiedad, bien como constructos afines como autoaceptación, mindfulness, auto-regulación emocional y autocrítica.

Palabras clave: Autocompasión, adaptación, validación.

Self-compassion is rather new to Western but not to Eastern psychology. Derived from Buddhist psychology (Neff, 2003a, 2003b, 2004), this construct entails how people deal with suffering in their lives, how they treat themselves in doing so, and how these experiences may be a source of self-knowledge. More importantly, being self-compassionate does not entail comparing oneself to others concerning how the person excels in something (a virtue, a skill, a goal).

With a bit more than a decade of empirical psychological research, self-compassion research value is its potential contribution to health contexts that require, for instance, attention to emotional regulation, a sense of belonging and interconnectedness, and clarity of thought. The positive psychology movement has been studying these and other psychological processes (Neff \& Lamb, 2009).

Self-compassion (SC) is compassion directed to the self. Neff (2003a) initially proposed that
SC encompasses three mechanisms: mindfulness versus over-identification, self-kindness versus self-judgment, and common humanity versus isolation. Later on, as will be described, the author realized that in fact SC is composed of the components that form the three mechanisms, but in a six-factor structure (Neff, 2003b).

Being mindful requires recognizing one's own suffering, mistakes, flaws, or inadequacies, becoming aware of the negative feelings those experiences evoke, and avoiding fixating on them or dedicating the whole self to the suffering they bring. Thus, the mindful mechanism trumps both over-identification with the flaw and its negation. The second mechanism involves acknowledging the suffering with this open mindset, but remaining kind and gentle to oneself while experiencing the negative feelings identified, without harshly judging or blaming oneself for the suffering experienced. SC is complete with the understanding that everyone suffers and thus no one needs to isolate him/ 
herself from other people because of one's own mistakes and weaknesses (Neff, 2003a, 2003b, 2004, 2009a, 2009b, 2012; Neff \& Lamb, 2009).

In addition, $\mathrm{SC}$ works in a balanced and interconnected system. The broadmindedness granted by mindfulness allows for a mindset of kind and welcoming acceptance of suffering - yet an active rather than passive acceptance - enabling a clearer picture of what is going on the self, and of the need for bringing it back to a healthier and more peaceful state. This broadened vision avoids over-identification with suffering, and a kind, warmth feeling towards it prevents harsh self-judgment and depreciation of oneself. This open and gentle attitude makes isolation more difficult. This is the case because since guilt, shame and other negative feelings do not overwhelm the person, her motivation to interact with other people, seek healing, or keep life going on may flourish. This prevents an attitude of isolation, by making it clear that suffering is part of human experience (Neff, 2003a, 2003b, 2004, 2009a, 2009b, 2012; Neff \& Lamb, 2009).

Neff (2003b) created the Self-Compassion Scale (SCS) in order to measure SC and offer a valid instrument for research and health intervention settings. The author conducted a pilotstudy and three validation studies, briefly described on the next section.

\section{Development and Validation of the Original Self-Compassion Scale by Neff (2003b)}

First, 68 United States (US) college students (mean age 21.7 years; 38 females) participated in focus groups (three to five persons) answering to open-ended questions about the aforementioned $\mathrm{SC}$ processes. Then the concept of SC was explained, followed by a previously prepared list of items for a potential scale, according to which participants should evaluate what was discussed in the focus group while ascribing the relative importance of the items to the concept presented. After eight weeks of modifications and focus groups, 71 students (mean age 21.3; 47 females), not previously involved in the study, read the potential items for the scale and marked the ones they judged confusing or unclear. Subsequently, participants received a small list of beliefs and values self-compassionate people endorse. According to the author, significant correlations were found between the potential scale items and the set of values and beliefs (for more details, see Neff, 2003b, p. 227).

The pilot testing of the SCS resulted in 71-scaled items, approximately one sixth representing each of the three mechanisms in their positive and negative characteristics (mindfulness versus over-identification, selfkindness versus self-judgment, and common humanity versus isolation). Following the pilot study, 391 undergraduate students (mean age $20.91 ; 225$ women,) were asked to mark, from 1 (almost never) to 5 (almost always), how often they behaved according to each of the 71 items. "Overall self-compassion scores were calculated by reverse coding the self-judgment, isolation, and over-identification items then summing all six subscales means" (Neff, 2003b, p. 243).

Exploratory factor analyses assessed SC components separately, which endorsed the exclusion of items with factor loadings lower than .40. Then confirmatory factor analyses examined goodness-of-fit, as well as whether there was one single higher-order factor accounting for the SC construct. A final solution of six factors was accepted $(\mathrm{NNFI}=.88 ; \mathrm{CFI}=.90)$ and internal consistency reached .92 with 26 of the 71 items analyzed (Neff, 2003b). The author concluded that the six-factor structure is indeed consistent with the measured construct. In failing to find a hypothesis for the three-factor structure (the three mechanisms), the choice for the six-factor structure was justified not only statistically, but also through analysis of the nature of the construct. Indeed, it is possible, for instance, for someone to be both high in self-kindness and high in self-criticism; nevertheless, such a person is not self-compassionate, according to Neff (2003a, 2003b, 2004).

The final six-factor structure of the SCS is as follows: self-kindness (SK; five items: 5, 12, 19, 23, 26), self-judgment (SJ; five items: 1, 8, 11, 16, 21), mindfulness (M; four items: 9, 14, 17, 22), over-identification (OI; four items: 2, 6, 20, 
24), common humanity $(\mathrm{CH}$; four items: $3,7,10$, 15), and isolation (I; four items: 4, 13, 18, 25). The reliability coefficient throughout the subscales varied from .75 to .81 and, again, .92 for the whole scale; factor loadings were between .62 and .80 ; inter-correlations between the six factors ranged from .46 to .91 (Neff, 2003b).

Neff (2003b) provided different evidences for scale validity. The SCS performed adequately throughout a set of tests, as follows: nonsignificant correlation with the Marlowe-Crowne Social Desirability Scale $(r=.05 ; p=.34)$, and significant correlations with a self-criticism scale $(r=-.65 ; p<.01)$, a social connectedness scale $(r$ $=.41 ; p<.01)$, and with the subscales Attention $(r=.11 ; p<.05)$, Clarity $(r=.43 ; p<.01)$, and Repair $(r=.55 ; p<.01)$, that belong to the TraitMeta Mood Scale. In addition, participants with the highest scores in SC chose the sentence "I am kind to myself and others the same amount" (p. 233) more frequently than two other options presented (being kinder to oneself or being kinder to others). Results show that the SCS taps the same experiences the aforementioned scales measure.

Neff (2003a) considers the SCS as a healthy attitude toward oneself, for its relation to psychological health. He found significant negative correlations with self-criticism, depression, anxiety, rumination, thought suppression, and neurotic perfectionism; and positive correlations with life-satisfaction, social connectedness, and emotional intelligence. Neff (2003b) also examined correlations with health scales. After controlling for self-criticism, results showed significant correlations with: the Beck Depression Inventory $(r$ $=-.51)$, the Spielberger Trait Anxiety Inventory $(r=-.65)$, the neurotic perfectionism construct measured by the Almost Perfect Scale $(r=-.57)$, and the Satisfaction with Life Scale $(r=.45 ; \mathrm{p}$. 233).

In the process of developing and validating the SCS, study 2 had 232 undergraduate students (mean age $21.3 ; 145$ women) as participants. The author found significant correlations $(p<.01)$ with the following measures: Rosenberg Self-Esteem Scale $(r=.59)$; Berger's SelfAcceptance Scale $(r=.62)$; Self-Determination Scale $(r=.43)$; Basic Psychological Needs Scale (autonomy: $r=.42$; competence: $r=.52$; relatedness: $r=.25)$; Self-Rating Depression Scale $(r=$ -.55) and Spielberger State-Trait Anxiety Inventory - Trait Form $(r=-.66)$, both also significant after controlling for Rosenberg's self-esteem scale (-.34 and -.42, respectfully); Rumination Responses Scale $(r=-.50)$; White Bear Thought Suppression Inventory $(r=-.37)$; and Emotional Processing subscale $(r=.39)$ of the Emotional Coping Scale. Three weeks later, the same participants filled out the SCS again, and test-retest performance. The correlations found were: .93 for the overall score, .88 for SK, for SJ and for OI, .80 for $\mathrm{CH}$, and .85 for I and M. In sum, results from study 2 contributed to endorse the SCS, as expected by Neff (2003b).

A third study completed the development and validation of the SCS (Neff, 2003b). Buddhist practitioners from various parts of the US received an invitation to answer the SCS and the Rosenberg Self-Esteem Scale by email. The potential participants belonged to a Buddhist e-mail list-serve that practice Vipassana, a meditation technique "that intentionally cultivates mindfulness, insight into the interdependence of all beings, and compassion for self and others" (p. 242). Forty-three persons (mean age 47 years; 27 women) returned data by email, and years of practice with meditation ranged from 1 to 40 .

Compared to the undergraduates from study 2 , Buddhists scored higher in SC $(p<.0005)$, in SK, CH, and M $(p<.001)$; and lower in SJ, I, and OI $(p<.001)$. The difference between the SCS and the Self-Esteem Scale was nonsignificant $(p=.08)$, although referred by Neff (2003b) as marginally significant (p. 243). The effect size for group differences examined indicated that the meditation practice has more impact on SC than on self-esteem; hence, they are two independent constructs. SC scores showed a positive and significant correlation with years of practice $(r=.35 ; p<.05)$. Results from study 3 , therefore, report relevant contributions to the validation of the SCS. All studies taken together, the author supplied enough evidence to guarantee that the scale is valid, ready for use in English, and able to capture what $\mathrm{SC}$ entails. 
Using Neff's (2003b) SCS with US participants, Neff, Rude, and Kirkpatrick (2007) report significant positive associations between $\mathrm{SC}$ and constructs such as happiness, optimism, positive affect, wisdom, personal initiative, curiosity and exploration, agreeableness, extroversion, and conscientiousness. In a different study, the authors conducted an experiment with the use of a short conflict resolution exercise. People who "experienced an increase in self-compassion also experienced increased social connectedness and decreased self-criticism, depression, rumination, thought suppression, and anxiety" (Neff, Kirkpatrick, \& Rude, 2007, p. 149); associations were still significant after controlling for anxiety. Interestingly, although significant correlations were observed between SC and self-esteem in Neff's (2003b) original study, the latter was not able to provide a better support or buffer against negative feelings and experiences than the SCS (Leary, Tate, Adams, Allen, \& Hancock, 2007; Neff, 2011; Neff \& Vonk, 2009).

\section{Studies Reporting the Use of the SCS in Other Languages}

Since Neff (2003b) published the SCS, researchers from other parts of the world have been proposing translations, adaptations and evidences for different validation processes using samples outside the US. This section describes articles, published in English, which describe studies that used the SCS in other languages. They show variation on the amount of adaptation and validation procedures. Nonetheless, they show how scholars from different cultures have been showing interest in using the SCS since Neff (2003b) proposed it 11 years ago.

Neff, Pisitsungkagarn and Hsieh (2008) compared samples from Taiwan (164 undergraduate students, mean age 20.5 years, 119 females), Thailand (223 undergraduates, 19.8 years, 122 males), and the US (181 students, 21.4 years, 117 females) in terms of SC, Rosenberg's self-esteem, the Self-Construal Scale, the SelfRating Depression Scale, and the Satisfaction with Life Scale. In doing so, the authors provided an adaptation of the SCS to the Asian samples with translations and back-translations.
Factor analyses conducted showed the need to drop off one item from the Thai version and two items from the Taiwanese version; both versions yielded a scale reliability of .86. Amongst other results, Thais had the highest score in SC ( $p$ $<.001$ ), and post hoc tests suggested that the samples are clearly different concerning SC. Americans scored higher on self-esteem ( $p<$ .001 ), also with the confirmation of post hoc tests; interestingly, both Thai and Taiwanese students did not differ significantly from each other on Rosenberg's measure. This latter result and the authors' conclusion that "cross-cultural differences were not explained by differences in independent versus interdependent selfconstrual" as well as that "self-construal had a different pattern of association with selfcompassion in each cultural context", show that $\mathrm{SC}$ is experienced differently across cultures, but remains theoretically sound within each sample and while facing distinct self-measures. Nonetheless, the Thai and the Taiwanese versions of the SCS were based solely on translation. It is of interest to point out, however, that this study did not have the validation of SCS as a primary objective.

Deniz, Kesici, and Sümer (2008) conducted the adaptation and validation of the SCS for use in Turkey. First, authors translated the measure into Turkish and compared with another translation made by three university professors who are fluent in English. After proper modifications, 66 English teachers answered the Turkish version and the original SCS, with a two-week interval between administrations. This equivalence test yielded a significant relationship $(r=.96 ; p<$ $.001)$ that supported the Turkish translation for subsequent use.

In phase two of the study, 341 Turkish university students (mean age 19.81 years; 54\% female) filled out the instrument. Factor analyses showed evidences for a five-factor structure, and helped explaining the exclusion of items 1 and 22, which had factor loadings below .30. Phase three, with 189 students (mean age 19.06 years; $68.8 \%$ female) randomly selected from the previous sample, found significant correlations with the Turkish SCS and the Rosenberg Self- 
Esteem Scale $(r=.62 ; p<.001)$, the Satisfaction with Life Scale $(r=.45 ; p<.001)$, the Positive Affect Scale $(r=.41 ; p<.001)$ and the Negative Affect Scale $(r=-.48 ; p<.001)$. Finally, phase four of the study had 93 university students (mean age 18.56 years; $66.7 \%$ female), also randomly selected, filling out the Turkish SCS, and again three weeks later. The reliability coefficient for the test-retest validity was .83 . The authors suggest further studies, especially because a previous adaptation of the SCS for Turkish culture resulted in a six-factor solution (Öveç, Akın \& Abac1, 2007, cited by Deniz et al., 2008; published in Turkish). In addition, the Turkish study aforementioned used the same sample to support all of its evidences. Different samples may provide additional evidences for validity.

In Ghorbani, Watson, Chen and Norballa (2012), 238 Iranian Shiite Muslims, students at University of Tehran (mean age 21.6; 125 men), answered a Persian version of the SCS (authors provided evidences for translation and backtranslation), the Rosenberg Self-Esteem Scale (reliability of .80) and measures on integrative self-knowledge, basic need satisfaction, depression, anxiety, and religious orientation. The SCS internal reliability was .84 , and the overall scale score correlated significantly $(p<.001)$ with self-esteem $(r=.28)$, integrative self-knowledge $(r=.38)$, anxiety $(r=-.24)$, and depression $(r=$ $-.36)$, as well as with the three basic need satisfaction subscales, which are autonomy $(r=.23$; $p<.001)$, competence $(\mathrm{r}=.22 ; p<.01)$, and relatedness $(r=.19 ; p<.01)$. There were no correlations among the SCS and the three subscales of the religious orientation measure. The authors seemed to rely greatly on a translated SCS for Persian. Moreover, and in the same line as Neff et al. (2008), Ghorbani et al. (2012) did not aim at validation of the SCS.

In a validation study conducted in Iran, 265 university students (mean age 22.1; 154 women), from different universities in Tehran, responded the SCS (Azizi, Mohammadkhani, Foroughi, Lotfi, \& Bahramkhani, 2013). After translation, back-translation, analysis by an English teacher, two psychologists, and group discussion with
30 psychology students, a confirmatory factor analysis indicated a six-factor solution, as predicted by the authors (p. 20). Significant ( $p$ $<.05$ ) correlations were detected between SCS and the Rosenberg Self-Esteem Scale $(r=.26)$, the Ruminative Response Scale $(r=-.36)$, the Beck Depression Inventory II $(r=-.17)$, and the Spielberger State-Trait Anxiety Inventory ( $r=$ -.36). Internal consistency reliability was .78 for overall SC, and varied from .79 to .93 along the six subscales. The authors highlighted that all items, except for three, presented factor loadings over .70. The three items, and respectful factor loadings, were item 12 (.36), item 19 (.33), and item 23 (.67; p. 21). Authors point out that representative samples are mandatory for subsequent research with the SCS in Iran. One could add that items 12 and 19 most probably deserved further examination.

Despite not having validation of the SCS as their main goal, Neff and Vonk (2009) translated the SCS into Dutch and used it in two studies. Gathering data by email for a larger research project, authors managed to collect 2,187 responses for study 1 (mean age 38.6; 74\% women; $62 \%$ with paid employment). With regard to the translation and adaptation of the SCS, study 1 only reports that "translation difficulties" (p. 32) demanded the elimination of two items; nevertheless, they were not identified. Study 1 showed significant correlations between the SCS and global self-esteem, self-esteem instability, contingent self-esteem, contingent self-worth/social approval, contingent self-worth/appearance, contingent self-worth/performance, social comparison orientation, public self-consciousness, self-rumination, narcissism, anger, and need for cognitive closure (p. 36). For study 2, the authors used the 26 items in a sample of 165 undergraduate students. According to Neff and Vonk (2009), hierarchical regression analyses indicated that "self-compassion predicted additional significant variance in happiness, optimism, and positive affect after accounting for self-esteem" (p. 42). There was no further comment concerning the Dutch translation used on both studies.

Four studies involving Latin-based languages used Neff's (2003b) SCS: one in Italy, 
one in Spain, and two in Portugal. Petrocchi, Ottaviani and Couyoumdjian (2014) carried out a validation study of the SCS for use in Italy. The scale was translated and back-translated with the collaboration of Italian speaking English translators and native English speakers with excellent knowledge of the Italian language (p. 2). A final discussion on differences between translations preceded the adapted version and its use with 424 participants (mean age 36.53 ; 259 women; $40 \%$ nonworking students) in an on-line data collection. The authors confirmed the six-factor solution after cutting off items 15 and 23 , due to cross-loading and ambiguity in meaning in the Italian language. Nevertheless, results did not support the presence of a single higher-order factor. Internal consistency of the subscales ranged from .71 to .85 . Thus, in the Italian sample analyzed, SC is a combination of six attitudes toward oneself rather than one underlying factor. The authors suggest the dimensionality of the SCS varies according to culture.

Garcia-Campayo et al. (2014) led a validation study with 268 health care field students (mean age 20.54; 59.7\% females) at University of Zaragoza, in Spain. Two researchers, unaware of the objective of the SCS, translating the SCS into Spanish; next, two bilingual linguistics experts provided a back-translation, which was compared to the original by a native Englishspeaking teacher. Discrepancies were group discussed to find mutual agreement. Confirmatory factor analyses endorsed the six-factor structure, with loadings ranging from .61 to .77 (p. 6). Cronbach's alpha for the overall score was .87 . Two test-retest exams with a two-week interval indicated a .92 correlation with a subsample. Significant correlations $(p<.01)$ with related constructs were: Mindful Attention Awareness Scale $(r=.41)$, Spielberger State-Trait Anxiety Inventory-Trait Form $(r=-.54)$, Beck Depression Inventory $(r=-.43)$, and Perceived Stress Questionnaire $(r=-.58)$. Authors acknowledged the nature of the sample as the main limitation of the study.

In Portugal, Fontinha (2009) used a translated and back-translated version of the SCS made by two university professors. The author managed to collect data from 130 university students (mostly Psychology; mean age 20.97; $89.2 \%$ women). An exploratory factor analysis through principal factor technique and Varimax rotation tested the original six-factor model obtained by Neff (2003b). Results did not support the original structure. Further factorial analysis endorsed a four-factor solution with factor loadings ranging from .41 to .79 , and two items (17 e 22, both from the M subscale) did not reached the minimum factor load required (.40). Fontinha named the resulting four factors as emotional self-regulation (items 2, 4, 6, $9,13,14,17,18,20,22,24,25$, in a bipolar constitution), self-acceptance (items 1, 8, 11, $16,23,26$, also bipolar), shared humanity (items $3,7,10,15$, unipolar), and self-soothing (items $5,12,19,21$, bipolar). Inter-factor correlations were between .37 and .57, and item-scale correlations ranged from .73 to .80 . No item was cut-off, and reliability sub-scales varied between .71 to .85 , and .91 for the scale. The author did not indicate limitations concerning sampling or the translation and adaptation processes. Thus, although pioneer in collecting data in a Portuguese-speaking country, the resulting measure needs further efforts for validation on samples from Portugal.

Castilho and Gouveia (2011) validated the SCS for use in Portugal in order to investigate relations between SC and adverse childhood experiences, psychopathology and social comparison. With help from a certified translator, the authors adapted the SCS and collected data with 631 university students (mean age 20.65; 468 women). Internal consistency for the overall score of the SCS was .89 , ranging from .73 to .84 for the sub-scales. Item-total correlations ranged from .23 to .61. Three items had item-total correlations equal to or below the minimum expected (.30). However as their exclusion did not enhance the Cronbach's alpha, authors decided to keep them: items $7(r=.23), 10(r=.28)$ and 22 $(r=.30)$. A test-retest in 34 students four weeks later yielded a .78 correlation. Significant correlations $(p<.01)$ were detected between SCS and the measures Depression Anxiety Stress Scales- 
Depression Subscale $(r=-.49)$, Social Comparison Scale $(r=.36)$, and Life Orientation Questionnaire Test-Revised (assesses optimism; $r=$ .59). The article has no information with regard to the details of the factor analyses conducted. Nonetheless, data shows that items remained within the original subscales (p. 214).

We still have no studies with samples from Brazil, the largest Portuguese-speaking country. The only scientific study that mentions SC, although as synonym for self-pity, is a psychiatric study about depression, which examined associations between distorted thoughts and depression through Beck's Inventory (Medeiros \& Sougey, 2010). Moreover, for the many differences that exist between the Portuguese language spoken in Portugal and the one spoken in Brazil, Castilho and Gouveia's (2011) Portuguese version would not work with Brazilian samples. Thus, adaptation and validation efforts are justifiable, especially when keeping in mind that the SCS might be an interesting and useful measure of psychological health.

\section{Objective}

The objective of this study was to provide evidence for construct validation and reliability for the adaptation of the SCS for use in Brazil. The author of the original scale consented with the study. We rely on Neff's (2003b) original work with the SCS, on the strengths and limitations of the validation studies in the previous section, and on guidelines for adapting tests from Hambleton, Merenda and Spielberger (2005).

We expect that a confirmatory factor analysis will endorse that the mechanisms that explain SC have a six-factor structure, indicating six separate but inter-correlated factors. We also expect that analyses will point out a single higher-order factor of SC, responsible for intercorrelations between factors.

\section{Method}

\section{Sampling}

We designed the data collection in an online research platform. The research lab website offered a link to the study. In addition, scholars from all over the country individually received an invitation email asking them to take part on the study and to collaborate by inviting students, colleagues, friends, and so on to access the link and answer the scales.

Nine hundred and forty-four people accessed the research link, six of which declined to participate, while 30 quit before opening the instruments' page. From the remaining 908 potential participants, it was necessary to eliminate some cases: 47 for not choosing male or female on the page about social and demographic data; 1 case for not being 18 years old; five for not being born in Brazil; and 126 for not filling out the SCS. The resulting sample of 759 participants had only 216 men; therefore, we selected all of them for analysis, and randomly selected the same amount of women from the remaining 543 female participants.

Initially the aim was to obtain 20 participants per item of the SCS, following criteria suggested by Pasquali (2012). We ended up with approximately 17 people per item, which is still adequate for factorial analyzes. The age varied from 18 to 66 years-old $($ mean $=32.5$ years; $S D=$ 11.1). The 216 men and 216 women were mostly from the states of Minas Gerais (27.8\%), São Paulo (23.6\%) and Rio Grande do Sul (22.5\%). There were no participants from the states of Acre, Piauí, or Roraima, and nine people were not in the country during data collection.

\section{Translation and Adaptation Procedures of the Self-Compassion Scale for Use in Brazil}

The adaptation consisted of nine steps. First, two independent translators (Brazilian scientific scholars with very good level of English) elaborated a Brazilian-Portuguese version. Second, the authors compared both translations with the help of theoretical and conceptual literature available. In addition, different dictionaries were consulted (EnglishEnglish, English-Portuguese/Portuguese English) and an English thesaurus. Thus, the instrument received some adjustments.

Third, a focus group with Psychology undergraduates and graduate students in Psychol- 
ogy discussed the version with the authors in order to check the understanding of the items presented. Group participants have different levels of familiarity with English spoken in the USA, as well as experience in development and validation of psychological tests. The discussion generated changes in some items.

Then we asked five adults, with varied educational levels and wage, to fill out the version. At this point, a lay perspective (i. e., a perspective from people outside the university or academic work was important). This fourth step yielded minor, yet relevant, suggestions from the volunteers. In addition, one of the volunteers showed considerable difficulties in understanding many the items. This person did not have a high-school degree. Considering this, we concluded that the SCS is more suitable for people with, at least, a high-school diploma.

To analyze further the items of the Brazilian version, we conducted a focus group with psychology undergraduates and with licensed psychologists with varied professional experiences in counseling, educational, forensic, and organizational psychology services, especially with adults with all sorts of difficulties and sufferings (topics relevant to the scale). This focus group was important because of the training in listening to patients and clients and, for that, the specific vocabulary that people use when talking during psychological treatment. This fifth step offered a fruitful discussion that generated alterations in some items.

The sixth step had 16 Nutrition major undergraduates filling out the Brazilian version, resulting in minor alterations. The seventh step had two bilingual experts on the validation of psychological tests and in research topics similar to SC comparing the version with the original scale in English. The experts suggested minimal modifications. Step number eight was backtranslation. The translator was not only expert in English and Brazilian-Portuguese, but also very well trained in Buddhist philosophy, which Neff (2003b) mentions as the conceptual background of SC. The ninth and final step had Neff herself check the back-translated version and suggest three minor but important changes. After this, the authors concluded the adaptation process of the items of the SCS for use in Brazil.

The original format of the SCS requires the respondent to write a number from 1 (almost never) to 5 (almost always) in a blank space at the left side of each item. For the Brazilian adaptation, we chose a Likert five-point scale at the right side of each one of the 26 items, for that seems more visually friendly.

\section{Research Instruments and Data Collection}

A brief sentence preceded the link inviting for a research on self-knowledge, requiring a minimum age of 18 years, high-school degree, and having been born in Brazil. The first page provided the participant with the informed consent form, at the end of which there were two alternatives: "yes, I agree to participate on this research", which lead to page 2 of the instrument set; or "no, I do not agree in participating on this research", which would be followed by a message of thanks. Page 2 presented social and demographic questions, ended by the request to inform if the participant was male or female. Depending on the answer, a gender specific format of the SCS was shown. Data collection took place between October and November 2012, after gathering a minimum of 260 answers of each gender.

Before statistical analyses, all negative items were reverse-coded; it was the case with some items from the SJ subscale, the I scale, and the OI scale. Using the statistical software MPlus 6.12, we carried out a confirmatory factor analysis (CFA) with WLSMV estimation method (robust weighted least squares), goodness-of-fit indicators RMSEA (root mean square error of approximation, 90\% confidence interval - CI), CFI (comparative fit index, equal to or more than .90), and TLI (also known as NNFI - non-normed fit index, equal to or more than .90; Schreiber, Nora, Stage, Barlow, \& King, 2006). In addition, we performed interfactor correlations, and a higher-order factor analysis. The correlations of the information matrix yielded are polychoric, not Pearson's. 


\section{Results and Discussion}

The SCS for use in Brazil is available on Appendix, in Brazilian-Portuguese. Items have the same numbers as in the original SCS, available at www.self-compassion.org. Preliminary analysis revealed gender differences, similar to those found in the original study. Males presented a higher mean in Self-Compassion $(M=$
3.28; $S D=.65)$ than females $(M=3.10 ; S D=.74)$. This difference is significant $(p<.01)$ but the effect size is small $(d=.25)$. Age differences were also found between young adults (18-30 years, $M=3.06 ; S D=.66$ ) and older adults (31-66 years; $M=3.37 ; S D=.71)$. The difference is significant $(p<.01)$ and the effect size is rather large $(d=.41)$.

Considering that items are inter-correlated, the CFA with the original six-factor structure

Table 1

Factor Loadings and Standardized Error for the 26 Items of the Self-Compassion Scale-Brazil, per Sub-Scale

\begin{tabular}{|c|c|c|c|c|c|c|}
\hline \multirow[t]{2}{*}{ Item } & \multicolumn{6}{|c|}{ Sub-scale } \\
\hline & $\mathrm{SJ}$ & OI & $\mathrm{CH}$ & I & SK & M \\
\hline 1 & $.56(.040)$ & & & & & \\
\hline 8 & $.70(.030)$ & & & & & \\
\hline 11 & $.68(.033)$ & & & & & \\
\hline 16 & $.69(.029)$ & & & & & \\
\hline 21 & $.78(.028)$ & & & & & \\
\hline 2 & & $.69(.028)$ & & & & \\
\hline 6 & & $.70(.030)$ & & & & \\
\hline 20 & & $.76(.025)$ & & & & \\
\hline 24 & & $.67(.030)$ & & & & \\
\hline 3 & & & $.61(.042)$ & & & \\
\hline 7 & & & $.44(.046)$ & & & \\
\hline 10 & & & $.47(.045)$ & & & \\
\hline 15 & & & $.87(.033)$ & & & \\
\hline 4 & & & & $.71(.033)$ & & \\
\hline 13 & & & & $.82(.025)$ & & \\
\hline 18 & & & & $.67(.031)$ & & \\
\hline 25 & & & & $.82(.029)$ & & \\
\hline 5 & & & & & $.66(.029)$ & \\
\hline 12 & & & & & $.72(.029)$ & \\
\hline 19 & & & & & $.73(.025)$ & \\
\hline 23 & & & & & $.77(.027)$ & \\
\hline 26 & & & & & $.72(.027)$ & \\
\hline 9 & & & & & & $.72(.029)$ \\
\hline 14 & & & & & & $.76(.026)$ \\
\hline 17 & & & & & & $.66(.029)$ \\
\hline 22 & & & & & & $.75(.027)$ \\
\hline
\end{tabular}

Note. $\mathrm{SJ}=$ self-judgment; $\mathrm{OI}=$ over-identification; $\mathrm{CH}=$ common humanity; $\mathrm{I}=$ isolation; $\mathrm{SK}=$ self-kindness; $\mathrm{M}=$ mindfulness. All factor loadings statistically different from zero $(p<.001)$. 
yielded $\chi^{2}=895.900, d f=284, p<.001$; RMSEA $=.071(90 \%$ CI: .065-.076); CFI $=.937$; TLI $=.928$. These results suggest good indices (Schreiber et al., 2006). In addition, they show evidences that the SCS for Brazilian samples has a six-factor structure, as the original scale, and is in line with evidences for validity demonstrated by Azizi et al. (2013) and by Garcia-Campayo et al. (2014; Persian and Spanish versions, respectively). Table 1 shows factor loadings and standard error, per item. Factor loadings ranged from .44 to .87 .

Table 2 presents polychoric correlations between factors, which are all adequate. As Table 2 shows, interfactor correlation presented a high correlation between factors SI and I (.90).

Table 2

Polychoric Inter-Correlations between the Six Sub-Scales of the SCS-Brazil

\begin{tabular}{cccccc}
\hline & SJ & OI & CH & I & SK \\
\hline OI & .84 & & & & \\
CH & .46 & .51 & & & \\
I & .61 & .90 & .42 & & \\
SK & .77 & .69 & .70 & .53 & \\
M & .53 & .73 & .81 & .66 & .84 \\
\hline
\end{tabular}

Note. $\mathrm{SJ}=$ self-judgment; $\mathrm{OI}=$ over-identification; $\mathrm{CH}=$ common humanity; $\mathrm{I}=$ isolation; $\mathrm{SK}=$ self-kindness; $\mathrm{M}=$ mindfulness. Correlations calculated after reverse scoring the negative dimensions of the SCS (SJ, OI, and I).

At first, this statistical proximity between these factors could suggest they are measuring nearly the same construct. Nevertheless, going back to the conceptual background, one can realize that both SI and I represent a negative dimension of the concept of self-compassion related to the location of the self in relation to the world: being apart from people (I items), and treating self and suffering as united entities (OI items). Both movements may lead to termination of affective and social life, which makes both a path into isolation (to isolate from other people, and to isolate myself from everything, except from my suffering).

We also conducted a higher-order analysis (hierarchical model) to see if SC explains the inter-correlations between its six components.
Results were $\chi^{2}=1407.494, d f=293, p<.0001$; RMSEA $=.094$ (90\% CI: .089-.099); CFI $=$ $.885 ; \mathrm{TLI}=.873$. With these results at hand, we decided to perform an investigation through a bi-factor model (overall SC $\mathrm{x}$ sub-scales) for a better fit. Results suggested that, even though SC might be a trait, the components may vary, i.e., they do not weight the same in SC. Results were $\chi^{2}=1203.880, d f=273, p<.0001 ;$ RMSEA $=$ .089 (90\% CI: .084-.094); CFI $=.904$; TLI $=$ .886. All analyses taken into consideration, the SCS-Brazil seems to be assessing SC, which is able to explain the statistically acceptable relationships between the sub-scales that measure the mechanisms of the construct.

\section{Internal Consistency of the SCS-Brazil}

Internal consistency (Cronbach's alpha) of the 26 items of the SCS-Brazil is .92, the same reported on Neff's study (2003b). The internal consistency for the six original subscales ranged from .75 to .81 . For the Brazilian version, the alpha of each sub-scale was as follows: .77 for SJ; .76 for OI; .66 for $\mathrm{CH}$; .79 for I; .81 for SK; and .77 for $\mathrm{M}$. The internal consistency of the over-identification sub-scale (OI) was not very good (.66). This scale has only 4 items and we will need further studies to determine if the items need to be improved.

\section{Final Remarks}

The objective of this study was to provide evidences of adaptation, construct validation and reliability of the SCS for use in Brazil. Although more evidences of validity remain to be provided in the future, this study offers results that endorse the use of the SCS with Brazilian samples.

Nine steps guided the adaptation pro-cess, with the participation of translators, psychologists, students, Psychology scholars and experts in psychological assessment. The validation studies published so far all differ when producing adaptation evidences. We decided to go beyond translation and back-translation, aiming at diversified group discussions and pilot testing, trying to avoid the trappings of ambiguous items 
and particularly the cutting off items due to translation difficulties, such as were reported by Neff and Vonk (2009). The study also provided good evidences of reliability for the scale and sub-scales, adequate inter-correlations between factors, one higher-order factor to certify SC as a construct, and the contribution of each one of the six components to the construct as a whole.

Other validation evidences are mandatory, for instance, those with validated measures of similar constructs, available in Brazilian-Portuguese, such as with depression, anxiety and neuroticism measures, and with measures such as the Rosenberg self-esteem, the satisfaction with life scale, and the PANAS scales. After more validation evidences, health interventions that include mindfulness and acceptance will have a new measure to better detect changes in SC in Brazilian patients. Future studies with meditation practitioners and with Buddhist participants, as well as with other positive measures such as hope and optimism, will also be good addenda for the continuation of the validation studies of the SCS-Brazil.

\section{References}

Azizi, A., Mohammadkhani, P., Foroughi, A., Lotfi, S., \& Bahramkhani, M. (2013). The validity and reliability of the Iranian version of the SelfCompassion Scale. Iranian Journal of Clinical Psychology, 2(3), 17-23.

Castilho, P., \& Gouveia, J. (2011). Auto-compaixão: Estudo da validação da versão portuguesa da Escala de Auto-compaixão e da sua relação com as experiências adversas na infância, a comparação social e a psicopatologia [Selfcompassion: Validation study of the Portuguese version of Self-Compassion Scale and its relationship to adverse childhood experiences, psychopathology and social comparison]. Psychologica (Coimbra), 54, 203-229.

Deniz, M., Kesici, Ş., \& Sümer, A. (2008). The validity and reliability of the Turkish version of the Self-Compassion Scale. Social Behavior and Personality, 36(9), 1151-1160. doi:10.2224/ sbp.2008.36.9.1151

Fontinha, J. (2009). "Faz a ti mesmo aquilo que farias aos outros": Estilo de vinculação como de- terminante da compaixão e auto-compaixão [Do to yourself what you'd do to others: Attachment style as a determinant of compassion and selfcompassion]. (Master's thesis). Universidade de Lisboa, Lisboa, Portugal.

Garcia-Campayo, J., Navarro-Gil, M., Andrés, E., Montero-Marin, J., López-Artal, L., \& Demarzo, M. (2014). Validation of the Spanish versions of the long (26 items) and short (12 items) forms of the Self-Compassion Scale (SCS). Health and Quality of Life Outcomes, 12(4), 1-9. doi:10.1186/1477-7525-12-4

Ghorbani, N., Watson, P., Chen, Z., \& Norballa, F. (2012). Self-compassion in Iranian Muslims: Relationships with integrative self-knowledge, mental health, and religious orientation. International Journal for the Psychology of Religion, 22(2), 106-118. doi:10.1080/10508619.2011.63 8601

Hambleton, R., Merenda, P., \& Spielberger, C. (Eds.). (2005). Adapting educational and psychological tests for cross-cultural assessment. Mahwah, NJ: L. Erlbaum.

Leary, M., Tate, E., Adams, C., Allen, A., \& Hancock, J. (2007). Self-compassion and reactions to unpleasant self-relevant events: The implications of treating oneself kindly. Journal of Personality and Social Psychology, 92(5), 887-904. doi:10.1037/0022-3514.92.5.887. 887

Medeiros, H. L. V. de, \& Sougey, E. B. (2010). Distorções do pensamento em pacientes deprimidos: Frequência e tipos [Distortions of thinking in depressed patients: Frequency and type]. Jornal Brasileiro de Psiquiatria, 59(1), 28-33. doi:10.1590/S0047-20852010000100005

Neff, K. (2003a). Self-compassion: An alternative conceptualization of a healthy attitude toward oneself. Self and Identity, 2, 85-101. doi:10.1080/15298860390129863

Neff, K. (2003b). The development and validation of a scale to measure self-compassion. Self and Identity, 2, 223-250. doi:10.1080/15298860390209035

Neff, K. (2004). Self-compassion and psychological well-being. Constructivism in the Human Sciences, 9, 27-37.

Neff, K. (2009a). Self-compassion. In M. Leary \& R. Hoyle (Eds.), Handbook of Individual Differences in Social Behavior (pp. 561-573). New York: Guilford. 
Neff, K. (2009b). The role of self-compassion in development: A healthier way to relate to oneself. Human Development, 52, 211-214. doi:10.1159/000215071

Neff, K. (2011). Self-compassion, self-esteem, and well-being. Social and Personality Psychology Compass, 5(1), 1-12. doi:10.1111/j.17519004.2010.00330.x

Neff, K. (2012). The science of self-compassion. In C. Germer \& R. Siegel (Eds.), Compassion and wisdom in psychotherapy (pp. 79-92). New York: Guilford.

Neff, D., Kirkpatrick, K., \& Rude, S. (2007). Selfcompassion and adaptive psychological functioning. Journal of Research in Personality, 41, 139-154. doi:10.1016/j.jrp.2006.03.004

Neff, K., \& Lamb, L. (2009). Self-compassion. In S. Lopez (Ed.), The Encyclopedia of Positive Psychology (pp. 864-867). Malden, MA: WileyBlackwell.

Neff, K., Pisitsungkagarn, K., \& Hsieh, Y. (2008). Self-compassion and self-construal in the United States, Thailand, and Taiwan. Journal of Cross-Cultural Psychology, 39, 267-285. doi:10.1177/0022022108314544

Neff, K., Rude, S., \& Kirkpatrick, K. (2007). An examination of self-compassion in relation to positive psychological functioning and personality traits. Journal of Research in Personality, 41, 908-916. doi:10.1016/j.jrp.2006.08.002

Neff, K., \& Vonk, R. (2009). Self-compassion versus global self-esteem: Two different ways of rela- ting to oneself. Journal of Personality, 77(1), 23-50. doi:10.1111/j.1467-6494.2008.00537.x

Pasquali, L. (2012). Análise fatorial para pesquisadores [Factor analysis for researchers]. Brasília, DF: Laboratório de Pesquisa em Avaliação e Medida.

Petrocchi, N., Ottaviani, C., \& Couyoumdjian, A. (2014). Dimensionality of self-compassion: Translation and construct validation of the SelfCompassion Scale in an Italian sample. Journal of Mental Health, 23(2), 72-77. doi:10.3109/096 38237.2013 .841869

Schreiber, J., Nora, A., Stage, F., Barlow, E., \& King, J. (2006). Reporting structural equation modeling and confirmatory factor analysis results: A review. The Journal of Educational Research, 99(6), 323-337. doi:10.3200/ JOER.99.6.323-338

Souza, L. K. de, \& Hutz, C. H. (2013). Adaptação $e$ validação da Escala de Autocompaixão $e$ Comparações com Autoestima e Autoeficácia (Relatório final de pesquisa). Porto Alegre, RS: Universidade Federal do Rio Grande do Sul, Programa de Pós-Graduação em Psicologia.

Recebido: 08/09/2014

$1^{a}$ revisão: 22/01/2015 Aceite final: 28/01/2015 


\section{Appendix}

\section{Como eu geralmente lido comigo em momentos difíceis (Souza \& Hutz, 2013).}

Por favor, leia com cuidado antes de responder. Para cada frase, marque o número que mostra com que frequência você se comporta da forma descrita. Use a escala de 1 até 5 para marcar sua escolha, sendo que 1 corresponde a "quase nunca" (QN), e 5 significa "quase sempre" (QS). Não existem respostas certas ou erradas. Gostaríamos de sua opinião pessoal. Você pode escolher qualquer número de 1 até 5 .

Por favor, para cada frase, marque com um " $X$ " a sua resposta.

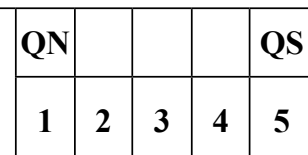

1. Sou realmente crítico e severo com meus próprios erros e defeitos.

2. Quando fico "pra baixo", não consigo parar de pensar em tudo que está errado comigo.

3. Quando as coisas vão mal para mim, vejo as dificuldades como parte da vida e que acontecem com todo mundo.

4. Quando penso nos meus defeitos, eu me sinto realmente isolado do resto do mundo.

5. Tento ser amável comigo quando me sinto emocionalmente mal.

6. Quando eu falho em algo importante para mim, fico totalmente consumido por sentimentos de incompetência.

7. Quando me sinto realmente mal, lembro que há outras pessoas no mundo se sentindo como eu.

8. Quando as coisas estão realmente difíceis, costumo ser duro comigo mesmo.

9. Quando algo me deixa aborrecido, tento buscar equilíbrio emocional.

10. Quando percebo que fui inadequado, tento lembrar que a maioria das pessoas também passa por isso.

11. Sou intolerante e impaciente com os aspectos de que não gosto na minha personalidade.

12. Quando estou passando por um momento realmente difícil, eu me dou o apoio e o cuidado de que preciso.

13. Quando fico "pra baixo", sinto que a maioria das pessoas é mais feliz do que eu.

14. Quando algo doloroso acontece, tento ver a situação de forma equilibrada.

15. Tento entender meus defeitos como parte da condição humana.

16. Quando vejo características que eu não gosto em mim, sou duro comigo mesmo.

17. Quando eu falho em algo importante para mim, tento ver as coisas por outro ângulo.

18. Quando passo por dificuldades emocionais, costumo pensar que as coisas são mais fáceis para as outras pessoas.

19. Sou bondoso comigo quando estou passando por algum sofrimento.

20. Quando algo me deixa incomodado, sou completamente tomado por sentimentos negativos

21. Costumo ser um pouco insensível comigo quando estou sofrendo.

22. Quando fico "pra baixo", tento aceitar e entender meus sentimentos.

23. Sou tolerante com meus próprios erros e defeitos.

24. Quando algo doloroso acontece comigo, costumo reagir de forma exagerada.

25. Quando eu falho em algo importante para mim, costumo me sentir muito sozinho nessa situação.

26. Tento ser compreensivo e paciente com os aspectos da minha personalidade dos quais não gosto.

Nota. O escore geral é calculado a partir da soma dos pontos marcados em cada item, divididos por 26. Os seguintes itens devem ser invertidos para o cálculo do escore geral da escala: 1, 2, 4, 6, 8, 11, 13, 16, 18, 20, 21, 24 e 25. 